\title{
KONTRIBUSI PERANTAU NAGARI ATAR KECAMATAN PADANG GANTING DALAM PEMBERDAYAAN BIDANG PENDIDIKAN
}

\author{
Irwandi \\ irwandi@iainbatusangkar.ac.id \\ IAIN Batusangkar
}

\begin{abstract}
Abstrak: Merantau salah satu tradisi masyarakat Minangkabau sudah berjalan secara turun temurun, tradisi ini timbul akibat dari geografis dan tipologi yang berdampak terhadap kehidupan dalam bidang ekonomi, sosial, dan pendidikan di Kampung halaman maupun di perantauan. Walaupun masyarakat Atar banyak yang berada di perantuan tetapi konstribusi terhadap kampung halaman tetap terpelihara baik terutama konstribusi bidang pendidikan. Teknik Analisa yang digunakan dalam penelitian ini adalah model interaktif dengan pendekatan kualitatif. Informan penelitian adalah Wali Nagari, Pengurus Perantau Nagari Atar, Lembaga Unsur dan Masyarakat. Dari Penelitian ini disimpulkan konstribusi Perantau terhadap Nagari Atar dibidang pendidikan diantaranya; pertama, adanya program satu rumah satu sarjana dalam bentuk bantuan Beasiswa Prestasi bagi anaka-anaka yang berasal dari keluarga kurang mampu, kedua, adanya rumusan bersama regulasi pendidikan anak-anak kampung halaman dalam meneruskan pendidikan ke jenjang pendidikan yang lebih tinggi serta wakaf tanah untuk kelanjutan pendidikan di Nagari Atar.
\end{abstract}

(Abstract: Migrating is one of the traditions of the Minangkabau people has been running from generation to generation, this tradition arises as a result of geography and typology which have an impact on life in the economic, social and educational fields in the hometown and in perantauan. Even though many of the Atar people are in assistance, the contribution to their hometown is still well preserved, especially the contribution to the education sector. The analysis technique used in this research is an interactive model with a qualitative approach. The research informants were the Wali Nagari, the Nagari Atar Monitoring Committee, the Elementary and Community Institutions. From this research, it is concluded that the contribution of Perantau to Nagari Atar in the field of education includes; first, the existence of a one house one undergraduate program in the form of Achievement Scholarship assistance for children who come from underprivileged families, second, the joint formulation of education regulations for hometown children in continuing education to a higher level of education and land waqf for continuation education in Nagari Atar.)

Kata Kunci: Pendidikan, Perantau, Nagari 
Irwandi

\section{A. Pendahuluan}

Merantau adalah sebuah tradisi di Minangkabau dan merupakan sebuah migrasi unik yang sudah sejak lama dikenal pada masyarakat luas. Menurut Hugo (1982) Migrasi di Indonesia telah menjadi budaya yang telah teraktualisasiakan kedalam beberapa etnis di Indonesia, migrasi menjadi suatu tradisi bagi orang-orang dalam kelompok tertentu untuk meninggalkan tempat kelahiran mereka, tentunya untuk mencari penghidupan yang lebih layak. Virzanira dalam Fakhrina (2017) mengemukakan migrasi suatu proses yang sangat selektif mempengaruhi individu dengan ciri-ciri sosial, pendidikan, ekonomi, dan demografi tertentu, maka pengaruhnya terhadap faktor ekonomi dan non ekonomi dari individu sangat bervariasi. Variasi itu tidak hanya pada arus migrasi antar wilayah dalam negara tetapi juga pada antar negara.

Tradisi merantau khususnya masyarakat Minangkabau di dorong oleh sifat, tingkah laku dan ketaatan orang Minangkabau terhadap tradisi yang mereka pelajari dikampung halaman dan menjadi modal utama untuk beradaptasi dengan daerah luar seperti ungkapan Naim (1984). Tradisi merantau bagi kaum laki-laki diberi kebebasan untuk pergi meninggalkan kampung halaman karena belum diperlukan didasarkan pada ungkapan Minangkabau yaitu "kerantau madang dahulu, babuah babungo balun, merantau bujang dahulu, di rumah paguno balun", maksudnya. disamping ungkapan di atas ada beberapa faktor yang menjadikan merantau sebuah tradisi di Minangkabau diantara diantaranya faktor ekonomi, faktor sosial dan faktor pendidikan, sedangkan faktor lain adalah faktor daya tarik lokasi merantau yang menyediakan kehidupan lebih baik di dunia usaha dan pendidikan serta peluang untuk membuka usaha baru.

Tradisi merantau yang dilakukan oleh masyarakat Minangkabau memberikan dampak kepada pembangunan di daerah asal, perhatian perantau terhadap kampung halaman khususnya di bidang agama, ekonomi, sosial dan pendidikan sangat tinggi, sehigga tradisi lain yang berkembangan sangat ini adalah tradisi mudik atau orang Minangkabau mengatakan dengan Pulang Basamo (pulang bersama) yang dilaksanakan oleh organisasi-oraganisasi perantau baik bersifat lokal, daerah, wilyah, nasional maupun International. Pulang Basamo biasanya dilaksanakan pada waktu libur lebaran hari raya Idul Fitri. 
Tradisi Pulang Basamo beriringan dengan silaturrahim memberikan dampak terhadap pembangunaan di daerah masing-masing, Seringkali pertemuanpertemuan antara perantau dan ranah yang di laksanakan oleh warga melahirkan ide-ide yang bertujuan untuk mendukung pembangunan di berbagai sektor di wilayah masing-masing baik pada sektor fisik maupun non fisik. Ide-ide yang lahir dari pertemuan silaturrahmi dimaksud tidak terlepas dari pola komunikasi dalam kehidupan sosial yang dilakukan antara perantau dan ranah, menurut Hasan(2010) pola komunikasi ini lahir dari hubungannya dengan proses sosial, komunikasi menjadi sebuah cara dalam melakukan perubahan sosial (social change). Komunikasi berperan menjembatani perbedaan dalam masyarakat karena mampu merekatkan kembali sistem sosial masyarakat dalam usahanya melakukan perubahan. Lebih lanjut komunikasi juga tak akan lepas dari konteks sosialnya. Artinya ia akan diwarnai oleh sikap, perilaku, pola, norma, pranata masyarakatnya. Jadi keduanya saling mempengaruhi dan saling melengkapi, seperti halnya hubungan antara manusia dengan masyarakat (Hasan, 2010).

Pola komunikasi yang telah dibangun akan melahirkan konstribusi para perantau yang bisa dikembangkan, salah satunya adalah konstribusi terhadap pengembangan pendidikan di daerah Ranah. Berdasarkan Undang-undang pendidikan Republik Indonesia Nomor 20 Tahun 2003 Pasal 6 ayat 2 tentang Sistem Pendidikan Nasional menyatakan, setiap warga negara bertanggung jawab terhadap keberlangsungan penyelenggaraan pendidikan, hal ini sesuai dengan amanat pembukaan Undang-Undang Dasar Negara Republik Indonesia tahun 1945 terdiri dari; a. Pemerintah Negara Indonesia yang melindungi segenap bangsa Indonesia dan seluruh tumpah darah Indonesia dan untuk memajukan kesejahteraan umum, mencerdaskan kehidupan bangsa, dan ikut melaksanakan ketertiban dunia yang berdasarkan kemerdekaan, perdamaian abadi dan keadilan sosial, b. Pemerintah mengusahakan dan menyelenggarakan satu sistem pendidikan nasional yang meningkatkan keimanan dan ketakwaan kepada Tuhan Yang Maha Esa serta akhlak mulia dalam rangka mencerdaskan kehidupan bangsa yang diatur dengan undangundang,

Dalam mewujudkan hal tersebut maka peran serta dari seluruh pihak baik penyelenggara, pemangku kepentingan stekholders dan seluruh unsur yang ada di masyarakat seperti; organisasi sosial kemasyarakatan, organisasi keagamaan dan 
Irwandi

lembaga sosial masayarakat lainnya, hal ini secara inplisit wajib membantu terwujudnya pendidikan yang mengkolaborasikan kualitas intelektual, spiritual dan sikap (attitude) yang di lengkapi dengan kemampuan ketrampilan/skill untuk dapat bersaing pada tingkat lokal, nasional, regional maupun international. Hal ini sesuai dengan Pasal 54 Undang-undangan Sistem Pendidikan Nasional menyebutkan bahwa a) peran serta masyarakat dalam pendidikan meliputi peran serta perorangan, kelompok, keluarga, organisasi profesi, pengusaha, dan organisasi kemasyarakatan dalam penyelenggaraan dan pengendalian mutu pelayanan pendidikan, b) masyarakat dapat berperanserta sebagai sumber, pelaksana, dan pengguna hasil pendidikan.

Kajian ini disajikan sebagai pengembangan peran serta salah satu organisasi masyarakat yang dapat memberikan konstribusi besar terhadap kemajuan pendidikan di daerah adalah organisasi perantau dengan objek penelitian organisasi perantau Nagari Atar Kecamatan Padang Ganting Kab. Tanah Datar. Menurut Naim (1979) istilah merantau dari sudut sosiologi, setidaknya mengandung enam pokok unsur yaitu: pertama kemauan sendiri, kedua meninggalkan kampung halaman, ketiga dengan tujuan mencari penghidupan, keempat untuk jangka waktu lama atau tidak, kelima biasanya dengan maksud kembali pulang, dan keenam menuntut ilmu atau mencari pengalaman; dan ketujuh merantau ialah lembaga sosial yang membudaya.

Berdasarkan hal tersebut maka organisasi Perantau Nagari Atar yang di namakan dengan IWATAR (Ikatan Warga Atar) berupaya memaksimalkan peran sebagai organisasi sosial dan merupakan salah satu modal sosial yang ada. Peran serta perantau tersebut akan terlihat dari program kerja dan kegiatan yang telah dilakukan.

Berdasarkan library research yang dilakukan, penelitian yang relevan dengan penelitian ini adalah penelitian yang di lakukan oleh Emita dkk (2013) dalam penelitiannya menyatakan bahwa masyarakat Galogandang membentuk organisasi perantau yang bertujuan untuk mengkoordinir masyarakat perantau yang berada diluar ranah (kampong halaman) guna memperkuat rasa kekeluargaan yang bernaung dengan nama organisasi yaitu Ikatan Keluarga Perantau Galogandang (IKAPGA), dengan beberapa program kegiatan di daerah ranah yaitu pembangunan 
sarana dan prasarana, bak sumber air bersih, dan beasiswa bagi anak yang berprestasi yang berasal dari keluarga berkemampuan ekonomi rendah.

Lebih lanjut Fakhrina (2017) mengatakan bahwa merantau erat hubungannya dengan kampung halaman dan sebaliknya. Kampung halaman yang menciptakan para perantau ulung. Tradisi merantau sendiri terbentuk dari kebiasaan-kebiasan menjelajah masyarakat sebelumnya untuk sekedar melakukan transaksi perdagangan dan sejarah orang Minang pun menjadi ujung tombak kebiasaan itu untuk dilakukan. Merantau sendiri dianggap suatu cara untuk meningkatkan harga diri dan martabat keluarga, karena dengan merantau orang Minang dapat merubah kondisi kehidupan sosial. Adapun faktor yang mendorong mereka merantau adalah; 1) Faktor ekonomi dan demografi, tentunya faktor ini menjadi faktor utama orang Minang untuk merantau karena mereka anggap lahan pertanian dan tempat berdagang disana tidak dapat berkembang dan lama kelamaan akan terbatas. 2) Faktor pendidikan, biasanya pada kalangan kaum muda salah satu cara untuk merubah hidup dengan cara sekolah di tempat yang lebih baik. Hal ini dikarena fasilitas pendidikan di kampung halaman tidak sebaik di kota. 3) Faktor sosial, biasanya untuk membuktikan pada keluarga dan lingkungan dengan merantau bisa membuat kehidupan mereka menjadi lebih baik dan dapat merubah status sosial dalam lingkungan. 4) Faktor tradisi dan budaya yang membuat kebiasaan itu dilakukan terus menerus dan dipertahankan sampai sekarang.

Selanjutnya, merantau menurut Marta (2014) dalam penelitiannya menyatakan bahwa pertama, di Minangkabau merantau merupakan salah satu kebiasaan yang dilaksanakan turun temurun dan merupakan suatu bentuk pembuktian kemandirian diri dengan berdagang, menuntut ilmu, bekerja, dengan harapan berubah kehidupan kearah yang lebih baik. Kedua, merantau dapat ditipikasi menjadi 'motif untuk' (in order to motives) yang merupakan gambaran sebagai maksud, harapan, minat, rencana dan sebagainya, berorientasi pada masa depan dan 'motif karena' (because motives) merujuk pada pengalaman masa lalu, motif seseorang digambarkan bagaimana ia berperilaku selama merantau. Motif juga menentukan apa yang didapat dan apa yang akan dicari dalam merantau. Ketiga, merantau merupakan ditipikasi untuk mendapatkan pengalaman positif ataupun negatif. Pengalaman dalam menemukan suatu yang membuat bahagia dan 
Irwandi

merasa tersokong dalam menggapai cita-citanya. Pengalaman negatif dimakud adalah menjalani atau menemukan hal yanga menyedihkan diperantuan.

Penelitian ini mengkaji tentang peran perantau dalam pembangunan ranah (kampung halaman) khususnya dalam bidang pendidikan. Penulis memfokuskan pada kajian Konstribusi Perantau Dalam Pengembangan Pendidikan (Tinjuan Pengembangan Masyarakat Islam Bidang Pendidikan di Nagari Atar Kecamatan Padang Ganting Kabupaten Tanah Datar). Tujuan penelitian ini adalah untuk memahami dan melakukan eksplorasi terhadap konstribusi perantau nagari Atar dalam bidang pendidikan, bentuk-bentuk konstribusi yang dilakukan dan bagaimana solusi dalam yang dilakukan untuk meningkatkan kualitas pendidikan di Nagari Atar yang dimaksud.

Penelitian ini menggunakan metode kualitatif dengan pendekatan Deskriptif. Metode kualitatif menurut Creswell dalam Herdiansyah (2012) menyatakan bahwa penelitian kualitatif adalah suatu proses penelitian ilmiah yang lebih dimaksudkan untuk memahami masalah-masalah manusia dalam konteks sosial dengan menciptakan gambaran menyeluruh dan kompleks yang disajikan, melaporkan pandangan terperinci dari sumber informasi, serta dilakukan dalam setting yang alamiah tanpa adanya intervensi apapun dari peneliti. Data yang dikumpulkan pada penelitian ini adalah data primer dan data sekunder, adapun subjek dari penelitian ini adalah Konstribusi Perantau dalam membantu pembangunan sektor pendidikan di Nagari Atar Kec. Padang Ganting Kab. Tanah Datar dengan informan penelitian adalah; Wali Nagari, Ketua ikatan Perantau Atar, tokoh masyarakat yang tergabung dalam lembaga Unsur Nagari (BPRN, KAN, Alim Ulama Nagari, Unsur Pemuda, Unsur Cadiak Pandai dan Bundo Kanduan), kepala sekolah, pengurus rumah ibadah serta masyarakat umum.

Adapun lokasi penelitian ini dilaksanakan di Nagari Atar Kec. Padang Ganting Kab. Tanah Datar Provinsi Sumatera Barat. Metode yang di gunakan dalam penelitian ini adalah wawancara, observasi lapangan, dan studi dokumentasi. Teknik analisis data yang digunakan adalah analisa data teknik analis data model interaktif dari Miles dan Huberman berdasarkan pada data yang diperoleh dan tujuan 
penelitian, dengan langkah-langkah analisis data dengan langka-langkah reduksi data, display data dan penarikan kesimpulan seperti pada bagan berikut.

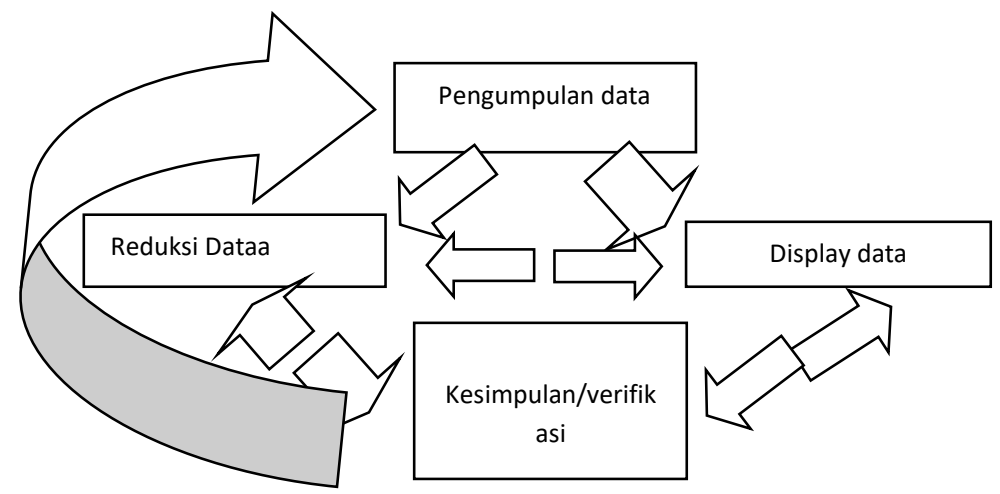

Model Interaktif Miles dan Huberman

\section{B. Pembahasan}

Penelitian ini dilaksanakan di Nagari Atar Kec. Padang Ganting Kab. Tanah Datar. Berdasarkan data sekunder dan informasi dari Wali Nagari, secara demografi jumlah penduduk Nagari Atar Tahun 2019 berjumlah 4821 jiwa dan secara geografis, Nagari Atar terletak pada 0032 LS-00 46 LS-100 , 44' BT- 100 53' BT. Pada sebelah barat berbatasan dengan Nagari Padang Ganting, sebelah Timur berbatasan dengan Nagari Taluak dan Nagari Tigo Jangko Lintau, sebelah Utara berbatasan dengan Nagari Nagari Pangian Lintau dan Nagari Tanjung Barulak dan sebelah selatan berbatasan dengan Nagari Talawi Kota Sawahlunto. Luas daerahnya adalah 50,25 kilometer persegi, berjarak $4 \mathrm{Km}$ dari ibu kota kecamatan dan $23 \mathrm{Km}$ dari ibu kota kabupaten. Nagari Atar didominasi wilayah perbukitan, dengan mata pencarian utama penduduknya adalah pertanian dan perkebunan, terutama perkebunan karet.

Dalam bidang pemerintahan Nagari Atar terdiri dari tiga Jorong yaitu Jorong Lareh Nan Panjang, Jorong Taratak VIII dan Jorong Taratak XII. Fasilitas yang dimiliki diantaranya; fasilitas pendidikan formal dan non formal. Fasilitas bidang ekonomi terdiri dari 2 (dua) buah pasar. Pada bidang pariwisata terdiri dari 2 (dua) buah tempat wisata alam dan wisata religi, sedangkan rumah ibadah yang ada 
Irwandi

sebanyak 68 buah terdiri dari 3 (tiga) masjid dan 65 (enam puluh lima) mushalla/surau. Dari segi adat istiadat, Nagari Atar memiliki 4 suku dan 20 orang Penghulu/Ninik Mamak dengan tugas dan fungsi masing-masing. Kehidupan sosial budaya diantarannya banyak masyarakat daerah ini yang melaksanakan tradisi merantau, sehingga berdampak terhadap kehidupan di kampung halaman baik dari segi pengembangan kegiatan keagamaan, kegiatan pendidikan, dan sosial kemasyarakatan.

\section{Potensi Pendidikan di Nagari Atar}

Fasilitas pendidikan formal di Nagari Atar terdiri dari; 4 buah PAUD, 5 taman kanak-kanak, 5 buah sekolah dasar dengan jumlah murid sebanyak 565 orang dan 1 buah SMP dengan jumlah murid sebanyak 183 orang. Adapun fasilitas pendidikan non formal terdiri dari 11 buah taman pendidikan Al-quran dan 2 buah Rumah Tahfiz. Ketersediaan sarana dan prasarana pendidikan di Nagari Atar cukup untuk menampung seluruh usia sekolah baik pada tingkat sekolah dasar sampai pada tingkat SMP. Namun dari hasil musyawarah yang dilaksanakan antara pihak perantau, Wali Nagari dan Lembaga Unsur serta masyarakat, terdapat beberapa kesimpulan yang mengacu kepada perkembangan pendidikan dan partisipasi masyarakat. dengan realitas sebagai berikut:

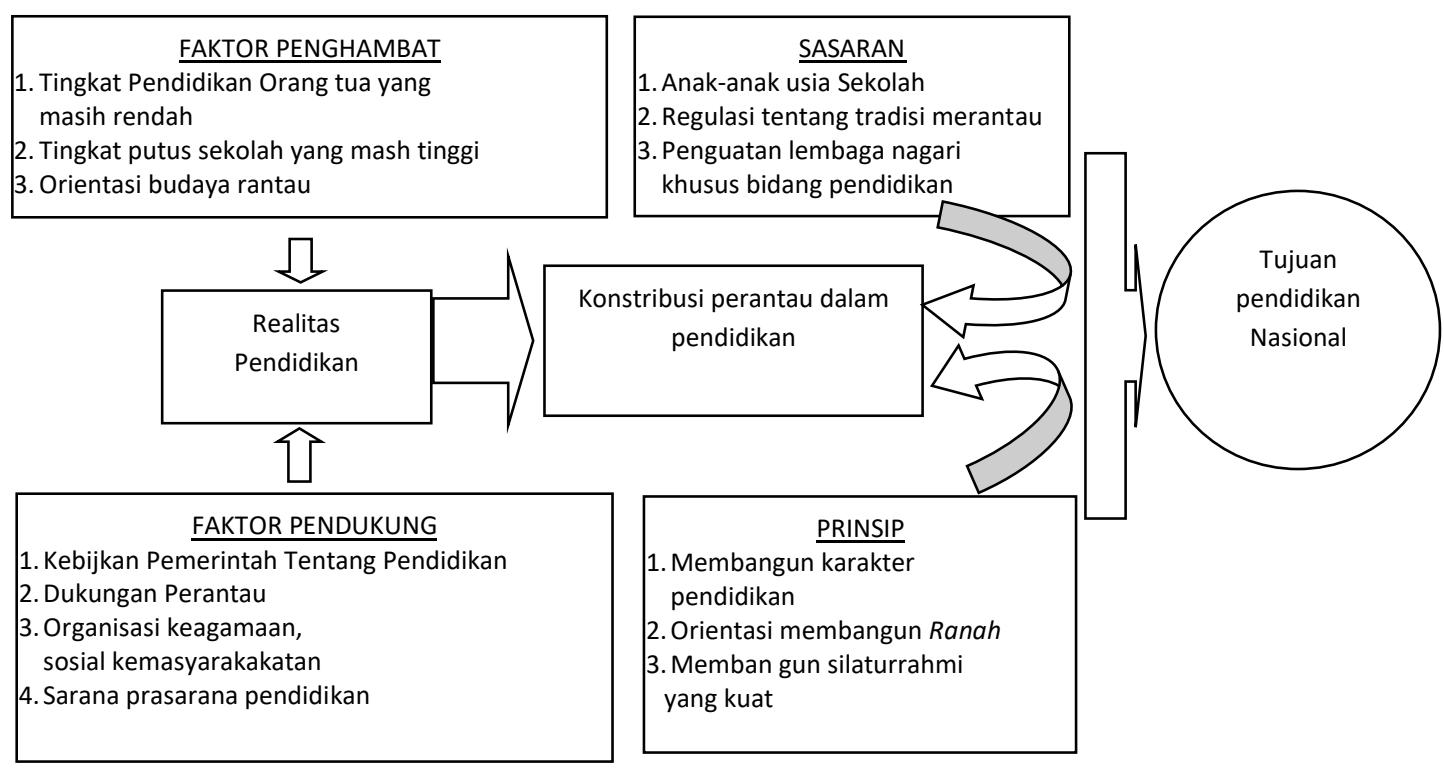


Dari gambar di atas dapat disimpulkan bahwa pengembangan potensi pendidikan di Nagari Atar berdasarkan realitas yang ada terdapat beberapa faktor faktor pendukung dan faktor penghambat yang memengaruhi. Beberapa faktor pendukung tersebut adalah kebijakan pemerintah tentang pendidikan, dukungan perantau terhadap ranah, adanya kegiatan sosial keagamaan serta sarana prasarana. Adapun beberapa faktor penghambat yakni tingkat pendidikan orang tua yang masih rendah, tingkat putus sekolah yang mash tinggi, orientasi budaya rantau yang selama ini berkembang yang mana menurut tokoh masyarakat setempat yakni adanya ungkapan dalam masyarakat "untuak apo sakolah tinggi-tinggi, nan ka dicari pitih juo" yang berarti untuk apa sekolah dilanjutkan pada tingkat yang paling tinggi, yang akhirnya akan berusaha untuk mendapatkan uang. Ungkapan ini sudah menjadi ungkapan yang turun temurun, sehingga banyak diantara orang tua yang menganjurkan anaknya untuk tidak melanjutkan pendidikan ke tingkat yang lebih tinggi.

Musyawarah yang dilaksanakan oleh Pemerintahan Nagari, perantau, lembaga unsur serta masyarakat merupakan salah satu bentuk kegiatan dalam mengembangkan potensi masyarakat. Muslim (2008) mengatakan bahwa potensi manusiawi yang paling penting dalam mengembangkan masyarakat adalah kemampuannya bermusyawarah mengenai kehidupannya, Dengan bermusyawarah masyarakat akan menemukan hakekat persoalan hidupnya. Kegiatan ini juga merupakan salah satu bentuk kegiatan modal Sosial. Menurut Aprillia dkk (2014), modal sosial adalah bentuk kebersamaan, kewajiban sosial yang diinstitusionalisasikan dalam bentuk kehidupan bersama, peran, wewenang, tanggungjawab, sistem penghargaan dan keterikatan lainnya yang menghasilkan tindakan kolektif. Modal sosial sebagai dasar pemberdayaan masyarakat dapat di gerakkan oleh seluruh lapisan masyarakat melalui fungsi, tanggungjawab dan tugas masing-masing masyarakat, sehingga seluruh konsep pembangunan dapat digerakkan masyarakat. Adapun menurut Wrihatnolo dan Dwidjowijoto (2007) bahwa konsep pembangunan yang digerakkan masyarakat dapat didefenisikan sebagai kontrol keputusan dan sumber daya komunitas. Ini merupakan kata kunci dalam mendefinisikan kegiatan sebagai bagian konsep pembangunan yang digerakkan masyarakat. Konsep tersebut salah satunya adalah partipasi masyarakat dalam menumbuh kembangkan kualitas dan kuantitas pendidikan di masyarakat. 
Irwandi

\section{Konstribusi Perantau dalam Pengembangan Pendidikan}

Kondisi daerah dengan topografinya yang berbukit-bukit dan bebatuan tidak memungkinkan untuk pengembangan bidang pertanian dalam menopang kehidupan masyarakat. Hal inilah yang menjadi faktor pendorong sebagian warga Nagari Atar untuk pergi merantau demi mendapatkan kehidupan yang lebih layak. Menurut Wali Nagari hampir 30\% warga Nagari Atar berada di perantauan dan tersebar diberbagai daerah di Indonesia baik di pulau Jawa, Sumatera, Kalimantan serta Bali. Perantau yang berasal dari Nagari Atar memiliki berbagai profesi yang dijalani mulai dari pedagang, pegawai negeri/swasta, pendidik dan lain sebagainya, namun yang paling terkenal dari daerah ini adalah hampir 90\% perantau dengan profesi sebagai wiraswasta dalam pelayanan jasa Foto Copy. Berkembangnya salah satu bentuk usaha ini karena dorongan yang kuat dari sesame kerabat perantau. Salah satu contohnya adalah memberikan modal kepada anak dan kemenakan untuk pengembangan usaha tersebut dan kegiatan ini telah dilaksanakan secara turun temuru. Dorongan dari perantau inilah yang berdampak terhadap kelangsungan pendidikan di Nagari Atar.

Keberhasilan para perantau Nagari Atar yang tergabung dalam paguyuban Ikatan Warga Atar (IWATAR) secara ekonomi telah menunjukkan hasil yang sangat memuaskan baik para perantau maupun bagi warga kampung halaman. Hal ini dibuktikan dengan didirikannya Tugu Fotocopy pada tahun 2012 di kampung halaman. Perhatian perantau terhadap kampung halaman tidak hanya sebatas mendirikan tugu tersebut tetapi juga memberikan perhatian dalam bidang sarana dan prasarana daerah setempat seperti mendirikan dan memperbaik masjid serta surau dan mendirikan gedung pertemuan. Begitu besarnya perhatian para perantau terhadap perkembangan Ranah mendorong pemeritahan Nagari untuk lebih menggiatkan berbagai kegiatan yang berkaitan dengan pembangunan non fisik, seperti perhatian terhadap kelanjutan pendidikan anak-anak di kampung halaman.

Menurut Wali Nagari, saat ini semakin banyaknya anak-anak yang putus sekolah sehingga memerlukan sinergisitas antara Ranah dengan para perantau untuk mengatasi persoalan tersebut karena kondisi yang sangat memprihatinkan itu akan berdampak terhadap masa depan Nagari Atar di masa yang akan datang. Banyaknya anak yang putus sekolah tidak saja karena akibat dari daya tarik untuk menjadi seorang perantau tetapi juga akibat dari rendahnya pendidikan orang tua serta 
tingginya angka perceraian. Berdasarkan realitas di atas maka dilaksanakan sebuah musyawarah antara Wali Nagari, lembaga unsur masyarakat dengan para perwakilan IWATAR yang menghasilkan kesepakatan sebagai berikut:

a) Program satu rumah satu sarjana.

Program satu rumah satu sarjana merupakan kesimpulan dan penyelesaian masalah pendidikan masyarakat di Nagari Atar. Program ini sepenuhnya didukung oleh warga rantau baik secara moril maupun materil. Dari hasil wawancara dengan ketua IWATAR, ia mengatakan bahwa dukungan terhadap kelanjutan pendidikan di kampung halaman akan selalu dilakukan, layaknya dukungan untuk membangun sarana prasarana di kampong halaman maka seperti itu pula dukungan terhadap perihal pendidikan masyarakat. Program satu rumah satu sarjana dimulai dengan melakukan pendataan kepada seluruh siswa dan tingkat ekonomi orang tua. Setelah dilakukan pendataan tersebut oleh Wali Nagari, maka data tersebut menjadi dasar bagi para perantau untuk membantu warga Ranah dalam bentuk pemberian beasiswa pendidikan.

Program ini tentunya menjadi perhatian semua pihak terutama dukungan dari keluarga. Hal ini sejalan dengan apa yang dikemukakan oleh Ki Hajar Dewantara dalam Junaedi (2009) bahwa keluarga merupakan pusat pendidikan yang bertanggung jawab tentang pendidikan budi pekerti. Pendidikan orang tua terhadap anak-anaknya merupakan pendidikan dasar yang tidak bisa diabaikan sama sekali sehingga orang tua hendaknya bijaksana dan pandai dalam mendidik anak. Baik buruknya pendidikan yang diberikan oleh orang tua terhadap anaknya sangat berpengaruh besar terhadap perkembangan dan pembentukan karakter pada anak, karena orang tua yang pertama berkomunikasi langsung dengan anaknya. Sejalan dengan hal di atas, pemerintah Kabupaten Tanah Datar melalui Peraturan Daerah Kabupaten Tanah Datar Nomor 1 Tahun tentang penyelenggaraan Pendidikan pada pasal 11 point a dan b menegaskan bahwa orang tua berkewajiban memberikan kesempatan yang seluas-luasnya kepada anaknya untuk memperoleh pendidikan, memberikan kesempatan kepada anaknya untuk berfikir dan berekspresi sesuai dengan tingkat intelektualitas dan usianya. 
Irwandi

b) Regulasi Pendidikan di Nagari Atar.

Menurut $\mathrm{KBBI}$ online, regulasi diartikan sebagai sebuah peraturan. Secara lebih lengkap, regulasi merupakan cara untuk mengendalikan masyarakat dengan suatu aturan atau pembatasan tertentu. Penerapan regulasi bisa dilakukan dengan berbagai macam bentuk yakni pembatasan hukum yang diberikan oleh pemerintah, regulasi oleh suatu perusahaan, dan sebagainya. Berdasarkan hasil wawancara dengan lembaga unsur masyarakat ditemukan bahwa salah satu latar belakang yang mendorong banyaknya anak yang putus sekolah di Nagari Atar diakibatkan oleh daya tarik kehidupan dirantau yang berpengaruh terhadap pola pendidikan di Ranah. Menindaklanjuti hal tersebut, dibuat sebuah regulasi yang dilaksanakan oleh warga rantau dan warga Ranah. Isi regulasi tersebut adalah warga rantau mendorong anak dan kemenakan meneruskan pendidikan ke jenjang yang lebih tinggi sebelum mereka terjun ke dunia bisnis/wiraswasta atau pekerjaan lainnya.

c) Wakaf untuk pembebasan lahan gedung SMP

Kondisi ekonomi masyarakat rantau yang semakin baik mendorong warga rantau untuk menyelesaikan masalah pendidikan yang menyangkut sarana dan prasarana. Salah satu persoalannya adalah penempatan fasilitas pendidikan SMP belum pada tempat yang tepat dan masih dipertentangkan oleh warga yang memiliki lahan tersebut. Maka dari itu, sesuai dengan kesepakatan bersama antara masyarakat Ranah dengan warga rantau, lahan tempat bangunan SMP yang bermasalah tersebut akan dibebaskan dengan iuran para perantau dan diwakafkan untuk warga Nagari Atar.

Ketiga bentuk kesepakatan ini telah mulai berjalan dan telah menampakkan hasil yang memuaskan, sehingga tujuan yang hendak dicapai dari undang-undang pendidikan secara umum dapat terlaksana dan tujuan dari para perantau dalam memajukan nagari Atar dapat berjalan dengan baik.

\section{Kesimpulan}

Konstribusi para perantau Nagari Atar dalam membangun kampung halaman dapat dikatakan sangat tinggi, perantau tidak hanya melakukan kontribusi pada bidang pembangunan fisik tetapi juga pada pembangunan non fisik seperti pembangunan dalam bidang pendidikan. Konstribusi tersebut bertujuan untuk 
meningkatkan meningkatkan kualitas masyarakat Ranah khususnya dibidang ilmu pengetahuan dan teknologi. Peningkatan kualitas Sumber Daya Manusia (SDM) yang dirintis oleh para perantau untuk kampung halaman melalui pemberian beasiswa kepada anak kemenakan di kampung halaman merupakan tidak lanjut dari hasil pertemuan atau musyawarah. Kesepakatan bersama inilah lahir beberapa kebijakan yakni adanya program satu rumah satu sarjana, regulasi pendidikan bagi anak kemenakan dan wakaf tanah untuk kelanjutan pendidikan pada masa yang akan datang. Konstribusi nyata ini tentunya perlu dukungan dari semua pihak termasuk pemerintah daerah Kab. Tanah Datar.

\section{Daftar Pustaka}

Aprillia T dkk. (2014). Pembangunan Berbasis Masyarakat. Penerbit Alfabeta Bandung (Cetakan kesatu).

Emita V, Zusmelia dan Marleni. (2013). Peran Perantau terhadap Pembangunan di Jorong Galogandang Nagari III Koto Kec. Rambatan Kab. Tanah Datar. Jurnal Ilmu Sosial Mamangan, 2 (1).

Fakhrina, Intan. (2017). Merantau dan Pulang Basamo: Studi Reinterpretasi Pola Migrasi pada Masyarakat Minangkabau di Bandar Lampung.

Hasan, Kamaruddin. (2010). Modul Komunikasi Sosial Dan Pembangunan. Program Studi IImu komunikasi Fakultas IImu Sosial dan IImu Politik Universitas Malikussaleh.

Herdiansyah, Haris. (2012), Metode Penelitian Kualitatif untuk IImu-ilmu Sosial. Jakarta Selatan: Salemba Humanika .

Hugo, Graeme J. (1982). Circular Migration In Indonesia. Population and Development Review, Vol.8, No. 1. https://doi.org/10.2307/1972690.

Junaedi, Mahfud. (2009). Kiai Bisri Musthafa: Pendidikan Keluarga Berbasis Pesantren. Semarang: Walisongo Press.

KBBI online. https://kbbi.web.id/regulasi.

Marta, Suci. (2014). Konstruksi Makna Budaya Merantau Di Kalangan Mahasiswa Perantau. Jurnal Kajian Komunikasi, 2 (1). 
Irwandi

Muslim, Aziz. (2008) Metodologi Pengembangan Masyarakat. Yogyakarta: Penerbit Teras.

Naim, Mochtar. (1984). Merantau Pola Migrasi Suku Minangkabau. Yogyakarta: Gadjah Mada University Press.

Peraturan Daerah Kabupaten Tanah Datar Tahun 2015 nomor 1.

Wrihatnolo, Randi R, Riant Nugroho Dwidjowijoto. (2007), Manajemen Pemberdayaan. Jakarta: PT. Elex. Media Komputindo. 